\title{
Sustainability of exercise-induced increases in bone density and skeletal
} structure

\author{
Magnus K. Karlsson, Anders Nordqvist and Caroline Karlsson \\ Clinical and Osteoporosis Research Unit, Department of Clinical Science and Department of Orthopaedics, \\ Malmö University Hospital, Lund University, Malmö, Sweden
}

Abstract

Background: The prevalence of osteoporosis with related fragility fractures has increased during the last decades. As physical activity influences the skeleton in a beneficial way, exercise may hypothetically be used as a prophylactic tool against osteoporosis.

Objective: This review evaluates if exercise-induced skeletal benefits achieved during growth remain in a longterm perspective.

Design: Publications within the field were searched through Medline (PubMed) using the search words: exercise, physical activity, bone mass, bone mineral content (BMC), bone mineral density (BMD) and skeletal structure. We based our inferences on publications with the highest level of evidence, particularly randomised controlled trials RCT.

Results: Benefits in BMD achieved by exercise during growth seem to be eroded at retirement, but benefits in skeletal structure may possibly be retained in a longer perspective. Recreational exercise seems to at least partially maintain exercise-induced skeletal benefits achieved during growth.

Conclusions: Exercise during growth may be followed by long-term beneficial skeletal effects, which could possibly reduce the incidence of fractures. Exercise during adulthood seems to partly preserve these benefits and reduce the age-related bone loss.

Keywords: bone mass; bone mineral content, BMC; bone mineral density, BMD; exercise; physical activity; skeletal architecture

Received: 26 March 2008; Revised: 22 July 2008; Accepted: 10 August 2008; Published: 01 October 2008

A s reviewed in an accompanying review (1) and reported in previous publications (2-12), the incidence of fragility fractures has increased during the last half of the 1900's. This is related to an increased prevalence of osteoporosis in society, predominantly due to an increased aging population (12-14). Whether the age specific incidence of osteoporosis has increased is unclear. Today there exist treatment of osteoporosis. Drugs to treat osteoporosis (15) have in randomised controlled trials (RCT) been shown to increase the bone mineral density (BMD) by $5-10 \%$ and reduce the fracture risk $(16,17)$. But other strategies for fracture prevention are also needed, strategies that influence BMD in a beneficial way without side effects and methods that are available for most individuals without high costs.

Epidemiological studies convincingly show that bone mass (BM) or bone mineral content (BMC) or BMD are closely associated with the risk of sustaining a fracture (18). A $10 \%$ decrease in BMD, corresponding to one standard deviation (SD), is associated with a doubled fracture risk (18). But, it is also imperative to realise that $\mathrm{BMD}$ is a poor predictor of the individual fracture risk, as so many other risk factors influence the risk of suffering a fracture $(4,13,18-20)$.

Physical activity during growth is associated with obvious skeletal benefits in both the accrual of bone mineral and gain in bone structure, especially in the late pre- and early peri-pubertal period (21-37). Mechanical strain that includes a high load, a fast load or a load affecting the skeleton in an unusual direction confers the highest anabolic response. The duration of exercise is of less importance, as a short duration of load or a small number of repetitions are enough to achieve the maximal anabolic effect. Thus, high intensity sports like squash, tennis, soccer, ice-hockey, badminton and volleyball are 
most effective if the goal is to reach skeletal benefits. But clinically relevant questions remain - do these exerciseinduced skeletal benefits remain with residual benefits into old ages, into the ages when the incidence of fragility fractures exponentially increases?

This review evaluates if the well-documented exerciseinduced skeletal benefits achieved during growth remain in a long-term perspective.

\section{Method}

The search for papers to be included in the review was done in Medline (PubMed). The search words: exercise, physical activity, bone mass, bone mineral content, bone mineral density, BMC, BMD and skeletal structure were used. Included in the review were only papers or abstracts published in the English language. No restriction on the time period studied was used, and studies in adults or those dealing with the long-term effects of exercise were included. From the relevant papers included in the Medline search, a further search was undertaken by choosing the connection 'related manuscripts'. Preferably, prospective, randomised controlled trials (RCT) were then included in this overview, as this is the highest ranked study design in evidence-based systems. If no RCT was found, the next level of evidence in the evidence-based hierarchy was scrutinised, i.e. non-randomised controlled studies, then retrospective and prospective observation cohort studies, and finally case-control studies. As an enormous amount of publications exists within this field and with these study designs, we predominantly included those with the largest sample size and the longest follow-up period. But, it must be emphasised that this is not a systematic review with prespecified inclusion criteria or a meta-analysis. Neither did we intend to include all papers published within this topic. Instead, we tried to interpret the enormous amount of data within the field in order to summarize the current concept within this topic.

\section{Results and discussion}

Are exercise-induced benefits in bone mineral density achieved during growth eroded by time?

Animal studies indicate a decline in exercise-induced benefits over time. One trial including 50 young rats, randomised to 8 or 12 weeks of training and then 4 weeks of detraining revealed that femoral wet weight, bone volume, cross-sectional area and cortical area all increased with the training regime, but that all benefits were lost with the 4 weeks of detraining (38). Another rat trial (39) supports that the effects of detraining should be followed for a long period, since all benefits in BMC were eventually lost with detraining (40). Bone turnover studies in humans do not oppose this view. Trials report that there are discrepancies in bone turnover when comparing active soccer players with retired soccer players. Another study reports that 2 weeks of detraining are followed by increased bone resorption and a decreaed bone formation.

However, there are reports that both support and oppose that exercise-induced BMD benefits are maintained after cessation of exercise (43-54). One crosssectional trial in tennis players infers that the arm to arm discrepancy in BMC remains undiminished after detraining. This suggests that benefits in BMC are maintained with reduced activity level (45). The prospective reports that support the maintenance of BMC or BMD benefits with cessation of exercise all have a questionable study design that could confound the conclusions. Some studies do not include more than 12 retired athletes (45), others include retired athletes still on a higher than average activity level, all studies have followed the former athletes only in a short period of retirement, and in one study that suggests BMD benefits to be retained with retirement, there is actually some regions with a higher BMD loss than in controls $(46,51-54)$. Therefore, we must be aware that these trials can include a type II error; the former athletes could still be on an activity level that influences the BMD, and the period of retirement could be too short to capture any increased age-related loss in BMD.

When looking at prospective data in a longer perspective of retirements, the results are less promising. One trial, at baseline including middle-aged runners, reported that 5 years later the loss in spine BMD was $13 \%$ in those who stopped running in comparison with $4 \%$ in those who continued to run (55). Similar data was reported in a short-term study, evaluating unilateral leg presses four times a week for 12 months in 12 women aged 19-27 years. The training period in this cohort was followed by a non-significant increase in BMD, but 3 months of detraining was followed by a return to the pre-training BMD level (56). Another similar report in 29 premenopausal women with regular training for 12 months supports this view. The programme was followed by a significant increase in BMD compared to 22 controls, but that all these benefits were lost with 12 months of detraining (57). There are now also two larger prospective controlled studies published that follow former athletes for 5-8 years into retirement $(43,44)$. The first study included 97 male ice-hockey and soccer players and 49 controls (43), and the second study included 66 female soccer players and 64 controls (44). Both reported that the athletes had a 1-1.5 SD higher BMD at baseline than controls, but after 4-5 years of retirement, the remaining exercise-induced benefits in BMD were approximately halved. These two studies revealed that the loss in BMD following retirement was greater than the age related loss in controls.

When evaluating the effect of retirement over decades, we have to rely on cross-sectional data. One trial including 
22 active and 128 former active male soccer players and 138 controls indicated that the former athletes still had higher BMD during the first two decades after retirement, but lower than the active soccer players (35). The diminution in leg BMD was $0.33 \%$ per year in the former soccer players compared to a loss of $0.21 \%$ per year in the controls (Fig. 1). After 5 years, the leg BMD was $10 \%$ higher than age-matched controls in the former players, after 16 years $5 \%$ higher but no longer higher in players retired for 42 years (Fig. 1). In spite of the more extensive loss with retirement, the leg BMD was $6 \%$ higher in the former soccer players, now over 70 years, than in controls, a non-significant difference when comparing unadjusted, but significant when comparing the values adjusted for differences in body composition (35). No benefits were seen in the hip, spine or any other skeletal region. The only variables that correlated with BMD in this study was age and current level of activity, not past level of activity. Also cross-sectional data in female former soccer players support this view. Twenty-five female former soccer players, aged 40 years and retired for 10 years, still had higher BMD than controls, however less than during their
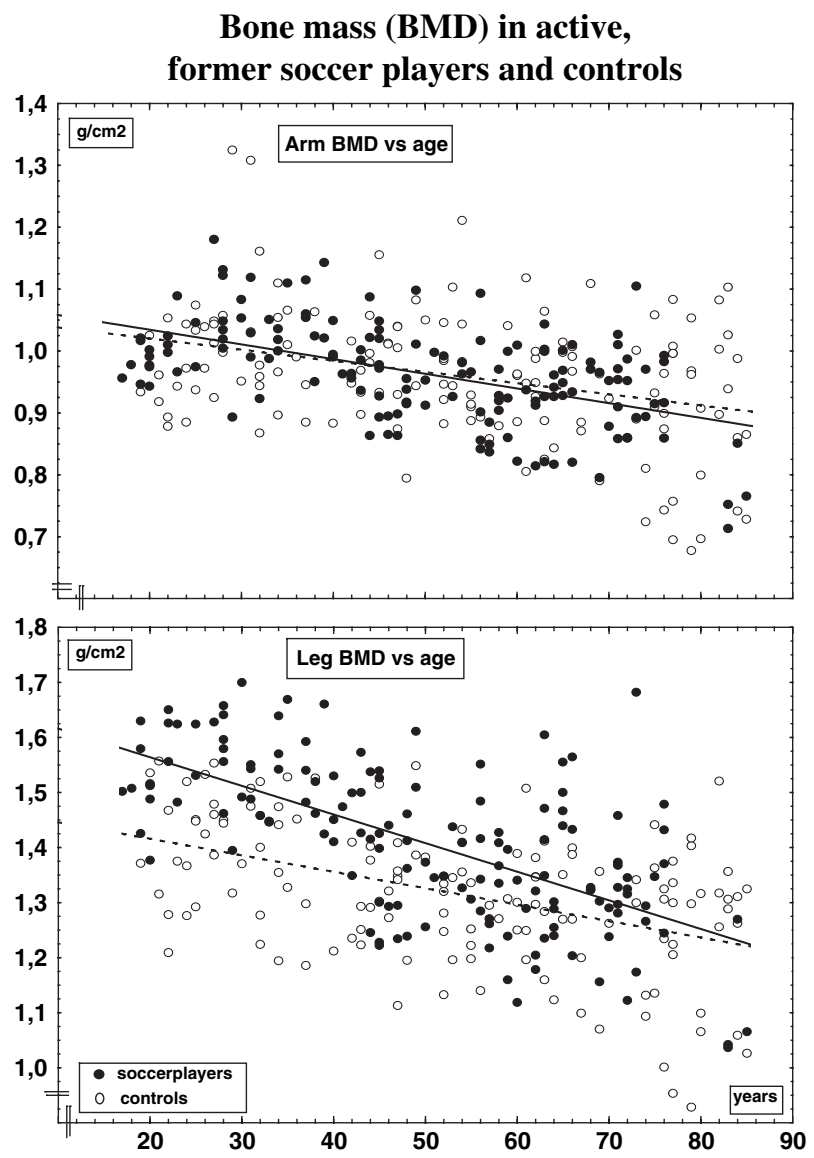

Fig. 1. Bone mass $\left(\mathrm{BMD}, \mathrm{g} / \mathrm{cm}^{2}\right)$ of the legs and arms in active, former soccer players and controls versus age. Adapted from Karlsson et al. (35). active career (58). These female athletes were unfortunately not followed in a long time perspective, so any residual benefits after age 65 could not be evaluated in this report. Also male former weight lifters had higher total body BMD after cessation from active career, by $8 \%$ when they were 35-49 years old, by 6\% at 50-64 year, but not higher than controls when they were 65-79 years (47-49). Similar data have been reported in retired professional male and female ballet dancers both in Australia (59) and Sweden (50), as well as in retired Australian gymnasts (34).

Are exercise-induced benefits in bone structure eroded by time?

Even if all benefits in BMD seem to be lost with detraining, there is a possibility that the structural changes, induced by exercise during growth, could be retained. The enlargement in bone size in the dominant upper extremity in former tennis players was maintained with cessation of exercise (45). In this study, 12 male former tennis players retired for 1-3 years were evaluated by peripheral computed tomography (pQCT). Humeral shaft arm to arm differences in total cross-sectional area of bone was $13 \%$ higher, cortical area $23 \%$, bone strength index $24 \%$, principle moments of inertia $41 \%$ and cortical wall thickness $20 \%$ higher compared to controls (45). The marrow cavity was also larger in the dominant arm suggesting that a greater endocortical expansion during activity or a higher endocortical resorption after retirement had occurred. The observations fit with the hypothesis that exercise produces enlargement of bone size that is permanent, but that the increased mineralisation through an endocortical apposition may be lost with retirement. Further, short-term studies from the same research groups support the view that cessation of exercise is associated with remaining benefits in bone structure (51-54). The same view was supported in a RCT, including 239 children aged 3-5 years (60). In this study, 12 months of physical activity including the large muscle groups was followed by both periosteal and endosteal expansion and these differences compared to controls remained with 12 months of detraining. This is probably of biological importance, as placing the cortical shell further away from the centre of the tubular bone will increase the bone strength by the fourth power of the radius (61).

But evaluation of benefits in a longer perspective has to rely on cross-sectional data. Bone size was larger in 90 male former soccer players and weight lifters aged 50-92 years and retired from their exercise career 3-65 years ago, in comparison with 77 sedentary age- and gendermatched controls, both at the femoral neck and the lumbar spine (62). Furthermore, in this study there were also remaining benefits in the old former athletes evaluated by quantitative ultrasound (QUS). This is of special interest as QUS usually estimates not only the 
quantity of bone mineral, but also the quality of the skeletal architecture (63), a trait not captured by the DXA technique. These latter data indicate that exerciseinduced structural skeletal changes, not captured by the DXA method, are possibly preserved in former athletes into old age and might then reduce the fragility fracture risk. However, further prospective cohort studies and long-term evaluated cross-sectional trials are needed to support such inferences.

\section{Conclusions}

Physical activity on a level that most individuals can perform increases the accrual of BMD during growth. Moderate activity seems to reduce the BMD loss in adulthood. The Achilles' heel of exercise is its cessation. Exercise-induced skeletal benefits in BMD achieved during growth seem to be lost with cessation of exercise, whereas exercise-induced structural benefits in the skeleton may be retained even with reduced activity level. Physically activity on a recreational level seems to retain some of the skeletal benefits achieved during growth.

\section{Recommendations}

Based on current scientific knowledge, we should recommend a continual physically active lifestyle during adulthood as one prevention strategy to reduce the high incidence of osteoporosis-related fractures.

\section{Acknowledgements}

Financial support was obtained from the University Hospital Foundations, Center for Sports Medical Research (CIF), the Swedish Society of Medicine, and the Swedish Society of Medical Research.

\section{Conflict of interest}

No conflicts of interest exist.

\section{References}

1. Karlsson MK, Nordqvist A, Karlsson C. Physical activity increases bone mass during growth. Food Nutr Res 2008. DOI: $10.3402 /$ fnr.v52i0.1871

2. Cooper C, Melton LJ, 3rd. Epidemiology of osteoporosis. Trends Endocrinol Metab 1992; 314: 224-9.

3. Cooper C, Melton LJ, 3rd. Magnitude and impact of osteoporosis and fractures. In: Marcus R, Feldman D, Kelsey J, eds. Osteoporosis. San Diego, CA: Academic Press; 1996. p. 419-34.

4. Johnell O, Gullberg B, Kanis JA, Allander E, Elffors L, Dequeker J, et al. Risk factors for hip fracture in European women: the MEDOS Study. Mediterranean Osteoporosis Study. J Bone Miner Res 1995; 10: 1802-15.

5. Kanis JA, Oden A, Johnell O, Jonsson B, de Laet C, Dawson A. The burden of osteoporotic fractures: a method for setting intervention thresholds. Osteoporos Int 2001; 12: 417-27.

6. Kannus P, Niemi S, Parkkari J, Palvanen M, Vuori I, Jarvinen M. Hip fractures in Finland between and 1970 and 1997 predictions for the future. Lancet 1999; 353: 802-5.
7. Kannus P, Parkkari J, Sievanen H, Heinonen A, Vuori I, Jarvinen M. Epidemiology of hip fractures. Bone 1996; 18: 57S-63S.

8. Melton LJ, 3rd, Atkinson EJ, Madhok R. Downturn in hip fracture incidence. Public Health Rep 1996; 111: 146-50; discussion 151

9. Bengner U. Epidemiological changes over 30 years in an urban population. Thesis. Lund, Sweden: Lund University; 1987.

10. Gullberg B, Johnell O, Kanis JA. World-wide projections for hip fracture. Osteoporos Int 1997; 7: 407-13.

11. Cummings SR, Melton LJ. Epidemiology and outcomes of osteoporotic fractures. Lancet 2002; 359: 1761-7.

12. Obrant KJ, Bengner U, Johnell O, Nilsson BE, Sernbo I. Increasing age-adjusted risk of fragility fractures: a sign of increasing osteoporosis in successive generations? Calcif Tissue Int 1989; 44: 157-67.

13. Kanis JA, Oden A, Johnell O, Johansson H, De Laet C, Brown $\mathrm{J}$, et al. The use of clinical risk factors enhances the performance of BMD in the prediction of hip and osteoporotic fractures in men and women. Osteoporos Int 2007; 18: 1033-46.

14. Ahlborg H, Johnell O, Järvinen T, Karlsson MK. Prevalence of low bone mass in women - secular trend over 30 years. J Bone Miner Res 2004; 19(Suppl 1): S49.

15. WHO. Assessment of fracture risk and its application to screening for postmenopausal osteoporosis. Report of a WHO Study Group. World Health Organ Tech Rep Ser 1994; 843: $1-129$.

16. Black DM, Cummings SR, Karpf DB, Caule JA, Thomson DE, Nevitt MC, et al. Randomised trial of effect of alendronate on risk of fracture in women with existing vertebral fractures. Fracture Intervention Trial Research Group. Lancet 1996; 348: 1535-41.

17. Orwoll E, Ettinger M, Weiss S, Miller P, Kendler D, Graham J, et al. Alendronate for the treatment of osteoporosis in men. N Engl J Med 2000; 343: 604-10.

18. Cummings SR, Nevitt MC, Browner WS, Stone K, Fox KM, Ensrud KE, et al. Risk factors for hip fracture in white women. Study of Osteoporotic Fractures Research Group. N Engl J Med 1995; 332: 767-73.

19. Marshall D, Johnell O, Wedel H. Meta-analysis of how well measures of bone mineral density predict occurrence of osteoporotic fractures. BMJ 1996; 312: 1254-9.

20. Jarvinen TL, Sievanen H, Khan KM, Heinonen A, Kannus P. Shifting the focus in fracture prevention from osteoporosis to falls. BMJ 2008; 336: 124-6.

21. Kannus P, Haapasalo H, Sankelo M, Sievanen H, Pasanen M, Heinonen A, et al. Effect of starting age of physical activity on bone mass in the dominant arm of tennis and squash players. Ann Intern Med 1995; 123: 27-31.

22. Mackelvie KJ, McKay HA, Khan KM, Crocker PR. A schoolbased exercise intervention augments bone mineral accrual in early pubertal girls. J Pediatr 2001; 139: 501-8.

23. MacKelvie KJ, McKay HA, Petit MA, Moran O, Khan KM. Bone mineral response to a 7-month randomized controlled, school-based jumping intervention in 121 prepubertal boys: associations with ethnicity and body mass index. J Bone Miner Res 2002; 17: 834-44.

24. Linden C, Ahlborg HG, Besjakov J, Gardsell P, Karlsson MK. A school curriculum-based exercise program increases bone mineral accrual and bone size in prepubertal girls: two-year data from the pediatric osteoporosis prevention (POP) study. J Bone Miner Res 2006; 21: 829-35.

25. Valdimarsson O, Linden C, Johnell O, Gardsell P, Karlsson MK. Daily physical education in the school curriculum in prepubertal girls during 1 year is followed by an increase in bone 
mineral accrual and bone width - data from the prospective controlled Malmo pediatric osteoporosis prevention study. Calcif Tissue Int 2006; 78: 65-71.

26. Bass SL, Saxon L, Daly RM, Turner CH, Robling AG, Seeman $\mathrm{E}$, et al. The effect of mechanical loading on the size and shape of bone in pre-, peri-, and postpubertal girls: a study in tennis players. J Bone Miner Res 2002; 17: 2274-80.

27. Kontulainen S, Sievanen H, Kannus P, Pasanen M, Vuori I. Effect of long-term impact-loading on mass, size, and estimated strength of humerus and radius of female racquet-sports players: a peripheral quantitative computed tomography study between young and old starters and controls. J Bone Miner Res 2002; 17: 2281-9.

28. Specker B, Binkley T. Randomized trial of physical activity and calcium supplementation on bone mineral content in 3- to 5year-old children. J Bone Miner Res 2003; 18(5): 885-92.

29. Lanyon LE. Control of bone architecture by functional load bearing. J Bone Miner Res 1992; 7: S369-75.

30. Rubin CT, Lanyon LE. Regulation of bone formation by applied dynamic loads. J Bone Joint Surg [Am] 1984; 66: 397-402.

31. Rubin CT, Lanyon LE. Regulation of bone mass by mechanical strain magnitude. Calcif Tissue Int 1985; 37: 411-7.

32. Turner CH, Woltman TA, Belongia DA. Structural changes in rat bone subjected to long-term, in vivo mechanical loading. Bone 1992; 13: 417-22.

33. Lanyon LE, Rubin CT. Static vs dynamic loads as an influence on bone remodelling. J Biomech 1984; 17: 897-905.

34. Bass S, Pearce G, Bradney M, Hendrich E, Delmas PD, Harding A, et al. Exercise before puberty may confer residual benefits in bone density in adulthood: studies in active prepubertal and retired female gymnasts. J Bone Miner Res 1998; 13: 500-7.

35. Karlsson MK, Linden C, Karlsson C, Johnell O, Obrant K, Seeman E. Exercise during growth and bone mineral density and fractures in old age. Lancet 2000; 355: 469-70.

36. Karlsson MK, Magnusson H, Karlsson C, Seeman E. The duration of exercise as a regulator of bone mass. Bone 2001; 28: 128-32.

37. Nilsson BE, Westlin NE. Bone density in athletes. Clin Orthop 1971; 77: 179-82.

38. Iwamoto J, Yeh JK, Aloia JF. Effect of deconditioning on cortical and cancellous bone growth in the exercise trained young rats. J Bone Miner Res 2000; 15: 1842-9.

39. Jarvinen TL, Pajamaki I, Sievanen H, Vuohelainen T, Tuukkanen J, Jarvinen M, et al. Femoral neck response to exercise and subsequent deconditioning in young and adult rats. $\mathrm{J}$ Bone Miner Res 2003; 18: 1292-9.

40. Pajamaki I, Kannus P, Vuohelainen T, Sievanen H, Tuukkanen $\mathrm{J}$, Jarvinen $\mathrm{M}$, et al. The bone gain induced by exercise in puberty is not preserved through a virtually life-long deconditioning: a randomized controlled experimental study in male rats. J Bone Miner Res 2003; 18: 544-52.

41. Karlsson KM, Karlsson C, Ahlborg HG, Valdimarsson O, Ljunghall $\mathrm{S}$. The duration of exercise as a regulator of bone turnover. Calcif Tissue Int 2003; 73: 350-5.

42. Karlsson KM, Karlsson C, Ahlborg HG, Valdimarsson O, Ljunghall S, Obrant KJ. Bone turnover responses to changed physical activity. Calcif Tissue Int 2003; 72: 675-80.

43. Nordstrom A, Karlsson C, Nyquist F, Olsson T, Nordstrom P, Karlsson M. Bone loss and fracture risk after reduced physical activity. J Bone Miner Res 2005; 20: 202-7.

44. Valdimarsson O, Alborg HG, Duppe H, Nyquist F, Karlsson M. Reduced training is associated with increased loss of BMD. J Bone Miner Res 2005; 20: 906-12.
45. Haapasalo H, Kontulainen S, Sievanen H, Kannus P, Jarvinen M, Vuori I. Exercise-induced bone gain is due to enlargement in bone size without a change in volumetric bone density: a peripheral quantitative computed tomography study of the upper arms of male tennis players. Bone 2000; 27: 351-7.

46. Heinonen A, Kannus P, Sievanen H, Pasanen M, Oja P, Vuori I. Good maintenance of high-impact activity-induced bone gain by voluntary, unsupervised exercises: an 8-month follow-up of a randomized controlled trial. J Bone Miner Res 1999; 14: $125-8$.

47. Karlsson MK, Hasserius R, Obrant KJ. Bone mineral density in athletes during and after career: a comparison between loaded and unloaded skeletal regions. Calcif Tissue Int 1996; 59: 245-8.

48. Karlsson MK, Johnell O, Obrant KJ. Is bone mineral density advantage maintained long-term in previous weight lifters? Calcif Tissue Int 1995; 57: 325-8.

49. Karlsson MK, Johnell O, Obrant KJ. Bone mineral density in weight lifters. Calcif Tissue Int 1993; 52: 212-5.

50. Karlsson MK, Johnell O, Obrant KJ. Bone mineral density in professional ballet dancers. Bone Miner 1993; 21: 163-9.

51. Kontulainen S, Kannus P, Haapasalo H, Heinonen A, Sievanen $\mathrm{H}$, Oja $\mathrm{P}$, et al. Changes in bone mineral content with decreased training in competitive young adult tennis players and controls: a prospective 4-yr follow-up. Med Sci Sports Exerc 1999; 31: 646-52.

52. Kontulainen S, Kannus P, Haapasalo H, Sievanen H, Pasanen M, Heinonen A, et al. Good maintenance of exercise-induced bone gain with decreased training of female tennis and squash players: a prospective 5-year follow-up study of young and old starters and controls. J Bone Miner Res 2001; 16: 195-201.

53. Kontulainen SA, Kannus PA, Pasanen ME, Sievanen HT, Heinonen AO, Oja P, et al. Does previous participation in high-impact training result in residual bone gain in growing girls? One year follow-up of a 9-month jumping intervention. Int J Sports Med 2002; 23: 575-81.

54. Kontulainen S, Heinonen A, Kannus P, Pasanen M, Sievanen H, Vuori I. Former exercisers of an 18-month intervention display residual aBMD benefits compared with control women 3.5 years post-intervention: a follow-up of a randomized controlled highimpact trial. Osteoporos Int 2004; 15: 248-51.

55. Michel BA, Lane NE, Bjorkengren A, Bloch DA, Fries JF. Impact of running on lumbar bone density: a 5-year longitudinal study. J Rheumatol 1992; 19: 1759-63.

56. Vuori I, Heinonen A, Sievanen H, Kannus P, Pasanen M, Oja P. Effects of unilateral strength training and detraining on bone mineral density and content in young women: a study of mechanical loading and deloading on human bones. Calcif Tissue Int 1994; 55: 59-67.

57. Winters KM, Snow CM. Detraining reverses positive effects of exercise on the musculoskeletal system in premenopausal women. J Bone Miner Res 2000; 15: 2495-503.

58. Duppe H, Gardsell P, Johnell O, Ornstein E. Bone mineral density in female junior, senior and former football players. Osteoporos Int 1996; 6: 437-41.

59. Khan KM, Green RM, Saul A, Bennell KL, Crichton KJ, Hopper JL, et al. Retired elite female ballet dancers and nonathletic controls have similar bone mineral density at weightbearing sites. J Bone Miner Res 1996; 11: 1566-74.

60. Specker B, Binkley T, Fahrenwald N. Increased periosteal circumference remains present 12 months after an exercise intervention in preschool children. Bone 2004; 35: 1383-8.

61. Ahlborg HG, Johnell O, Turner CH, Rannevik G, Karlsson MK. Bone loss and bone size after menopause. N Engl J Med 2003; 349: 327-34. 
62. Karlsson MK, Alborg HG, Obrant K, Nyquist F, Lindberg H, Karlsson C. Exercise during growth and young adulthood is associated with reduced fracture risk in old ages. J Bone Miner Res 2002; 17: S297.

63. Karlsson MK, Duan Y, Ahlborg H, Obrant KJ, Johnell O, Seeman E. Age, gender, and fragility fractures are associated with differences in quantitative ultrasound independent of bone mineral density. Bone 2001; 28: 118-22.

\section{Magnus Karlsson}

Department of Orthopaedics

Malmö University Hospital

Lund University

SE-205 02 Malmö, Sweden

Tel: +4640331000

Fax: +4640336200

E-mail: magnus.karlsson@med.lu.se 